\title{
INVESTIGATION OF THE COMPLEX DISASTER CAUSED BY DEBRIS FLOW AND FLOOD IN THE HIGASHI RIVER, SHIMATA RIVER SYSTEM DUE TO THE HEAVY RAIN IN JULY 2018
}

\author{
Nozomu ONAKA ${ }^{1}$, Yoshihisa AKAMATSU2 ${ }^{2}$, Takanori KONO 3 \\ and Kohei YAMAGUCHI 4 \\ ${ }^{1}$ Student Member of JSCE, Graduate School of Sciences and Technology for Innovation, Yamaguchi University \\ (2-16-1 Tokiwadai, Ube, Yamaguchi 755-0097, Japan) \\ E-mail: b004wdv@yamaguchi-u.ac.jp (Corresponding Author) \\ ${ }^{2}$ Member of JSCE, Professor, Graduate School of Sciences and Technology for Innovation, Yamaguchi University \\ (2-16-1 Tokiwadai, Ube, Yamaguchi 755-0097, Japan) \\ E-mail: yakamats@yamaguchi-u.ac.jp \\ ${ }^{3}$ Member of JSCE, Public Works Research Institute Aqua Restoration Research Center \\ (Government Land Reserve, Kasada, Kawashima, Gifu 501-6021, Japan) \\ E-mail: kouno-t277ck@pwri.go.jp \\ ${ }^{4}$ Member of JSCE, Center for Advanced Research, Research and Development Center \\ (2304 Inarihara, Tsukuba-shi, Ibaraki 300-1259, Japan) \\ E-mail: a9166@n-koei.co.jp
}

\begin{abstract}
The heavy rain in July 2018 caused debris flow and river flooding in the Higashi River in the Shimata River Basin in the Osogoe district of Iwakuni City, Yamaguchi Prefecture. In this study, we conducted a record of the disaster situation and field survey using an unmanned aerial vehicle (UAV) after the disaster in the Osogoe district. In addition, we conducted the orthoimages production, runoff analysis, and inundation analysis. The results showed that the causes of the inundation in the Osogoe district were 1) the significant rise in the riverbed due to the flowing of sediments and driftwoods carried by the debris flow and 2) the driftwoods blocking up the river flows at the bridge. In addition, The situation of the inundation analysis shows that the inundation would not have occurred without the influx of the debris flow. The area where the debris flow occurred was included in the landslide warning area. Therefore, the management strategy for afflicted areas like the Osogoe district needs to include predicting the direct inflow of the debris flow with a lot of sediment and driftwoods to the river segments.
\end{abstract}

KeyWords : heavy rain in July 2018, complex disaster, flood, debris flow, unmanned aerial vehicle

\section{INTRODUCTION}

From June 28 to July 8 in 2018 , the stagnant rainy season front and Typhoon No. 7 caused record-breaking heavy rains in a wide area from west Japan to the Tokai region. Over 230 lives were lost or had gone missing owing to the heavy rain, and there was enormous damage to houses, roads, railways, and public facilities $^{1)}$. In Yamaguchi Prefecture, human and material damage occurred, including 3 fatalities, 13 injured, 21 buildings destroyed, 448 partially destroyed, 95 partially damaged, 135 flooded above the floor, and 653 flooded below the floor. Sixty percent of the total damage occurred in Iwakuni and Shunan cities in the eastern part of Yamaguchi Prefecture. In the Osogoe area, one of the affected areas in Iwakuni City, large amount of sediments and driftwoods flowed from the riverside mountain into the Higashi River, which flows through the Osogoe area. The sediments and driftwoods were caught by a bridge located about $10 \mathrm{~m}$ downstream from the inflow point. The Higashi River was also flooded. The sake factory (Asahishuzo Co., Ltd.) was damaged by the flooding of the river, causing an estimated damage of about 1.5 billion yen.

As a study on past river disasters, Tsubaki et al. $(2014)^{2)}$ revealed the mechanism of flooding by airborne laser surveying and flood analysis in the mountainous area of the Asa River damaged by heavy precipitation in July 2010. Hashimoto et al. (2018) ${ }^{3)}$ has 


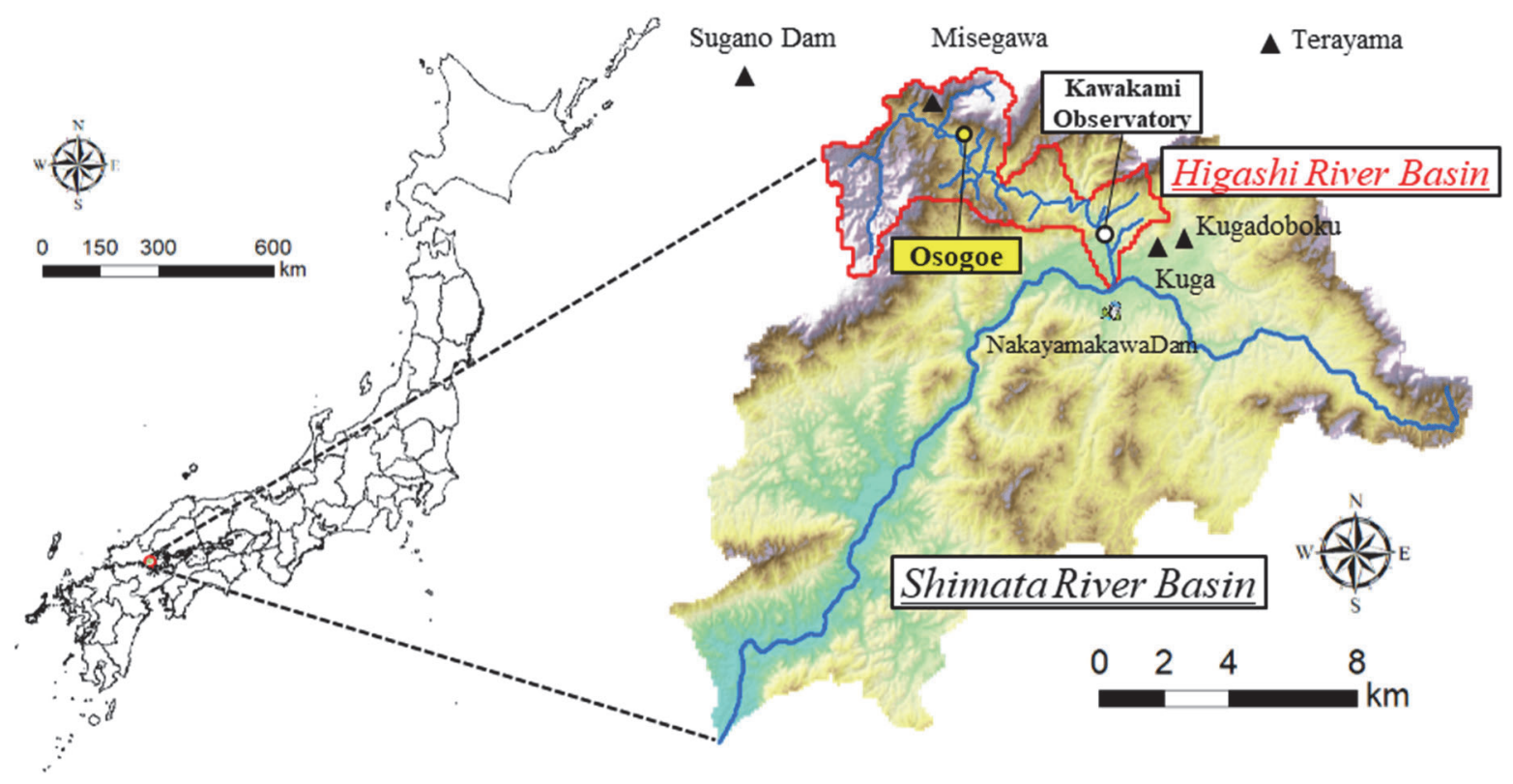

Fig.1 Location of the Osogoe district.

investigated the factors that influence flood by field survey and numerical simulation in Sumiyo Town in Amami City, which was affected by Amami heavy rain in 2010. Komuro et al. $(2018)^{4)}$ conducted reproduction simulation and the estimation of sediment deposition from river inundation by surveying unmanned aerial vehicle (UAV) equipped with laser profiler (LP) in the Sozu River, which was damaged by a complex disaster in northern Kyushu in 2017. Yamazaki et al. (2018) ${ }^{5)}$ suggested the method of estimating of collapse distribution due to rain on the Akatani River. Egashira et al. (2018) ${ }^{6}$ ) investigated the actual conditions of sediment runoff due to collapse and debris flow and examined methods for predicting fine sand runoff due to slope failure. Harada and Egashira et al. $(2018)^{7)}$ conducted an analysis on the behavior of fine sediment and driftwood within the flow of flood water in the mountain area.

Based on these studies, much knowledge on sediment flooding, river flooding, debris flow, and complex disasters have been obtained. However, there are few studies on complex disasters with sediment-related disasters and river flooding in mountainous areas. Thus, the elucidation of the actual conditions of complex disasters that occurred in the Osogoe area is very important for developing future disaster mitigation measures in mountainous areas. In this study, we conducted a reconnaissance survey and a UAV-based field survey for the complex disaster with debris flow and river flooding in the Osogoe district of Iwakuni City in Yamaguchi Prefecture in order to clarify the actual situation of the complex disaster.

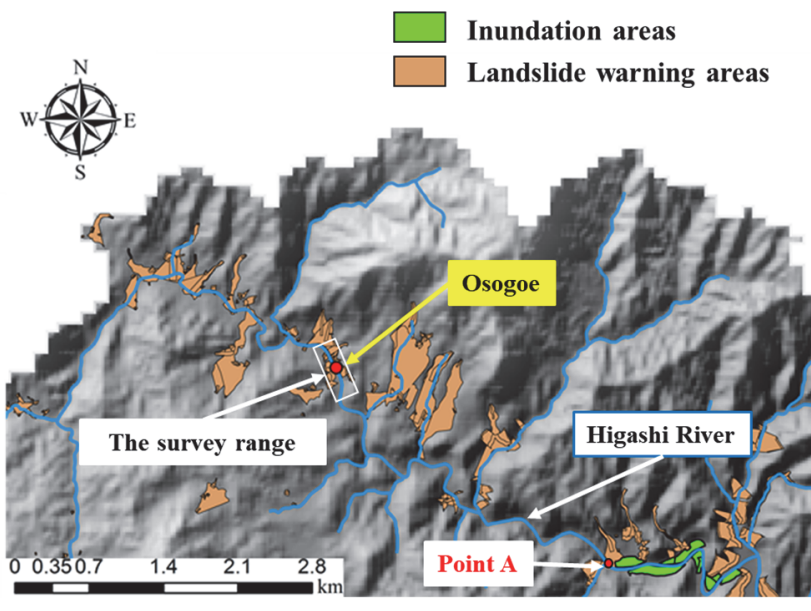

Fig.2 Possible inundation areas and landslide-prone areas around the Osogoe district.

\section{FIELD SURVEY}

\section{(1) Survey area}

The Osogoe district in Shuto Town in Iwakuni City, Yamaguchi Prefecture is a V-shaped valley that is located in the upstream of the Higashi River in eastern Yamaguchi Prefecture (Fig. 1). Shuhoku Elementary School and the headquarters of Asahi Shuzo Co., Ltd., a sake company, are in the Osogoe district. The Higashi River is a second-class river with a length of about $14.6 \mathrm{~km}$ and is a tributary of the Shimata River (basin area $269.5 \mathrm{~km}^{2}$, length 34.5 $\mathrm{km})$. In the Shimata River Basin, flood damage occurred due to the Makurazaki Typhoon, the Kiziya Typhoon, the rainy season front with a total precipitation of $598 \mathrm{~mm}$, and the Loose Typhoon in the 

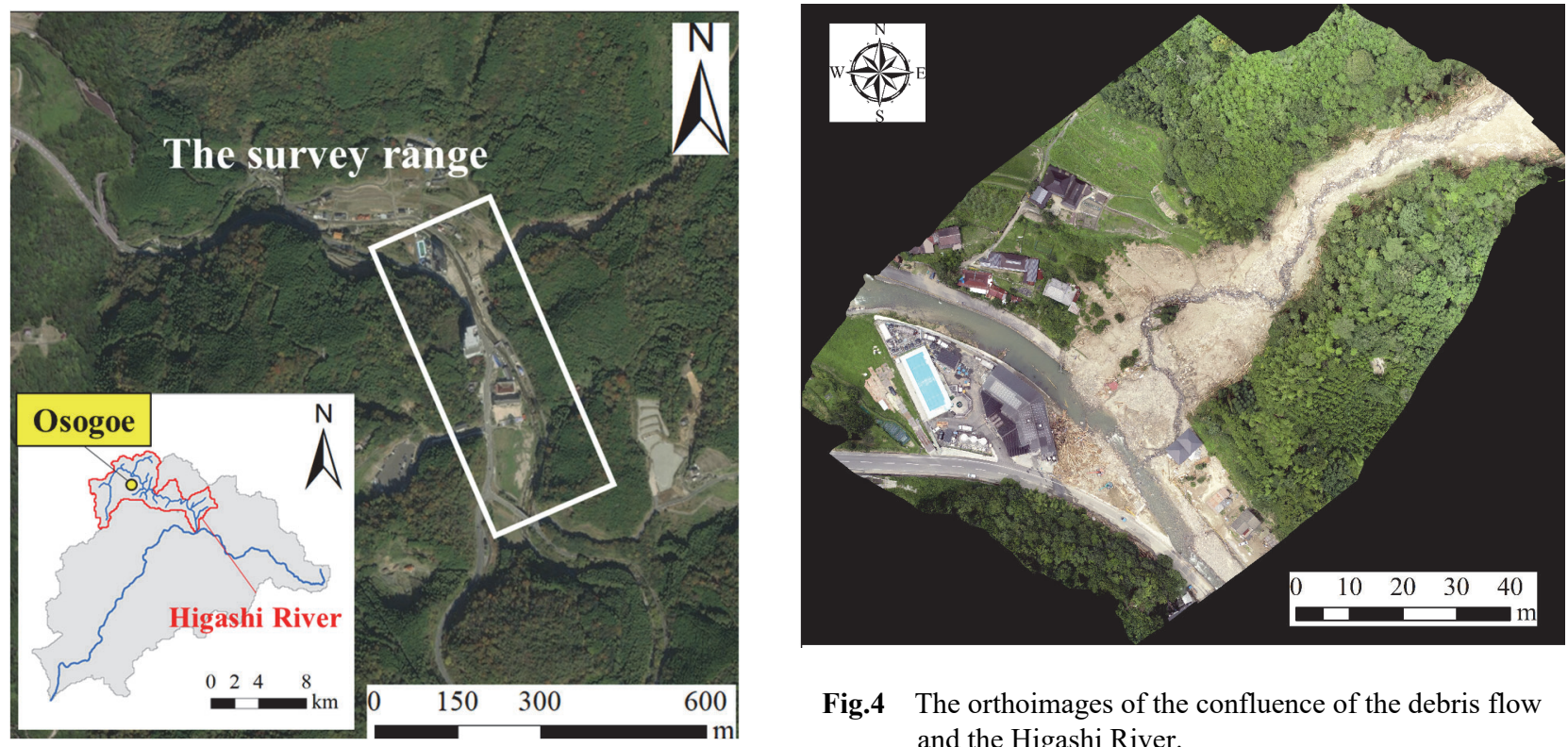

Fig.4 The orthoimages of the confluence of the debris flow and the Higashi River.

Fig.3 The survey range.

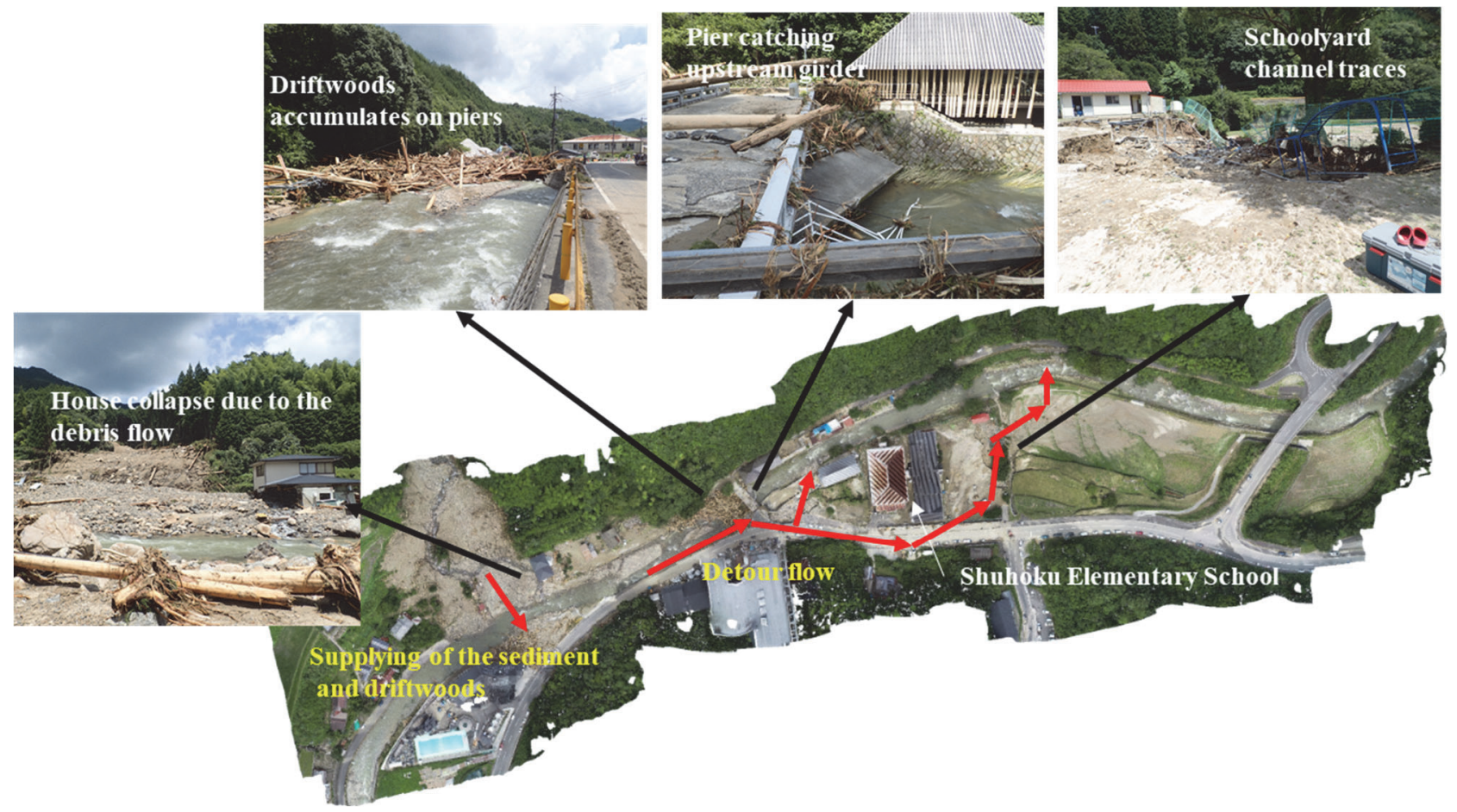

Fig.5 The orthoimages around the afflicted area and the damage situations.

1940s-1950s. Thus, a large-scale river improvement has been carried out in the Shimata River Basin. For example, the Nakayama River Dam with flood control function was constructed in $1996^{8)}$. In addition, Yamaguchi Prefecture has released information on the landslide and inundation-prone areas in the Shimata River Basin. Figure 2 shows landslide warning areas (Yamaguchi Prefectural Office, 2019) ${ }^{9}$ and the possible inundation areas (Yamaguchi Prefectural Office, 2009) ${ }^{8)}$ around the Osogoe district. In the Osogoe district, many landslide-prone areas had been identified. On the other hand, the consideration range of the possible inundation area in Yamaguchi Prefecture was up to point A in Fig. 2, and the Osogoe district was out of the range.

\section{(2) Field survey method}

The field survey was conducted on July 9 and July 11 in 2018 immediately after the disaster occurred, and on October 20 in 2018 approximately three months after the disaster occurred (the survey ranges are shown in Figs. 2 and 3). On October 20 in 2018, sediments and driftwoods that had flowed into the Higashi River due to debris flow had been completely 


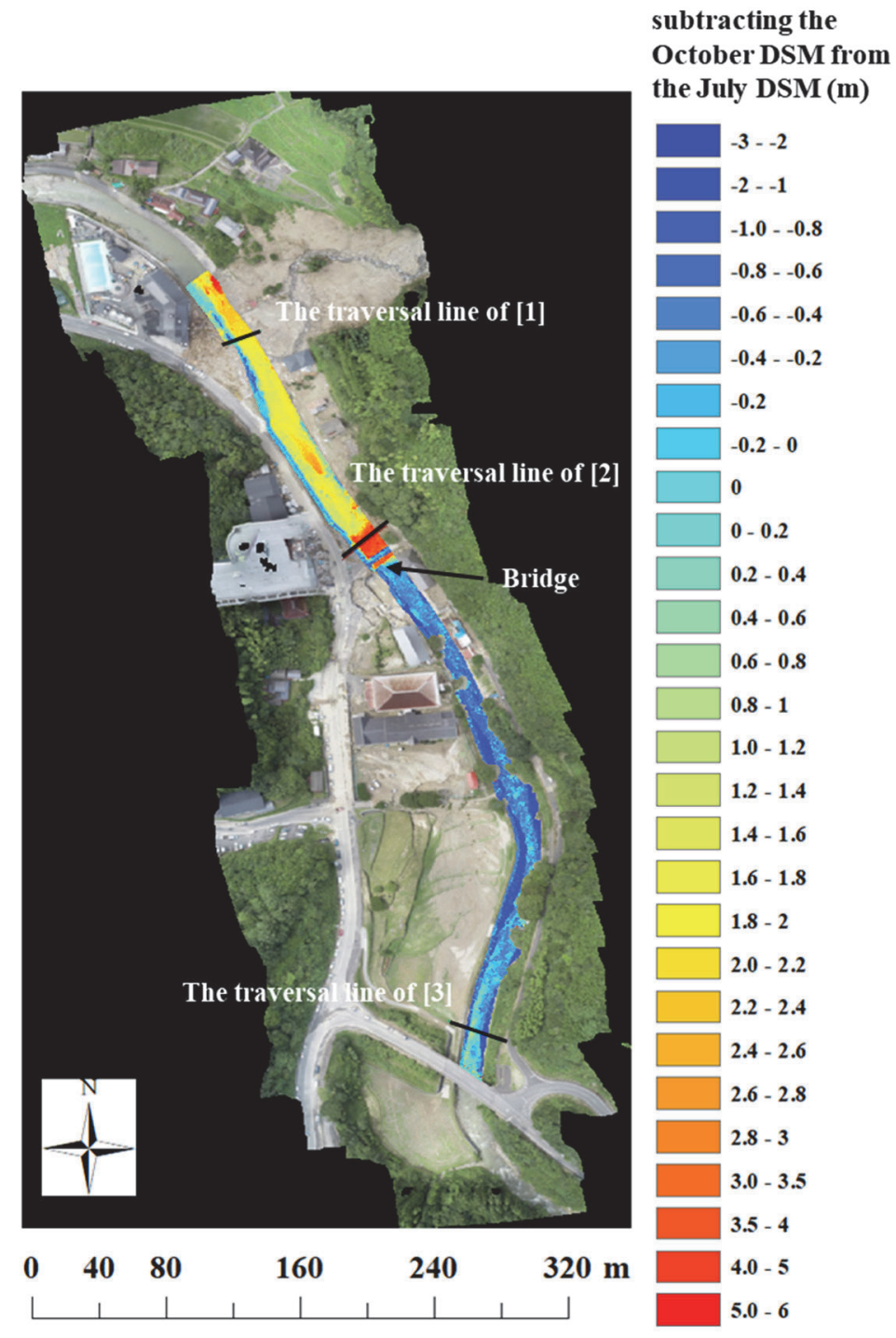

(a) The contour diagram of the river bed

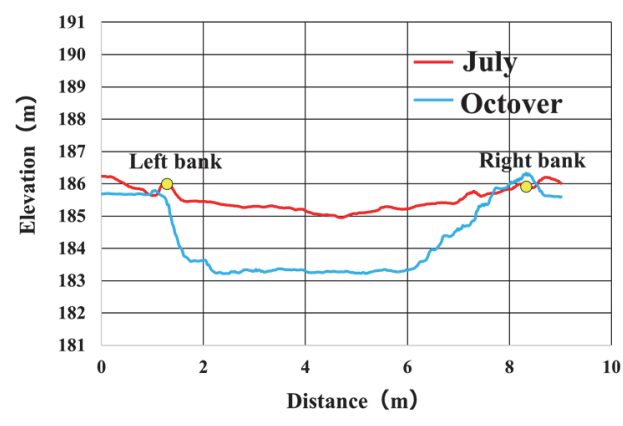

(b) Cross section of the traversal line [1]

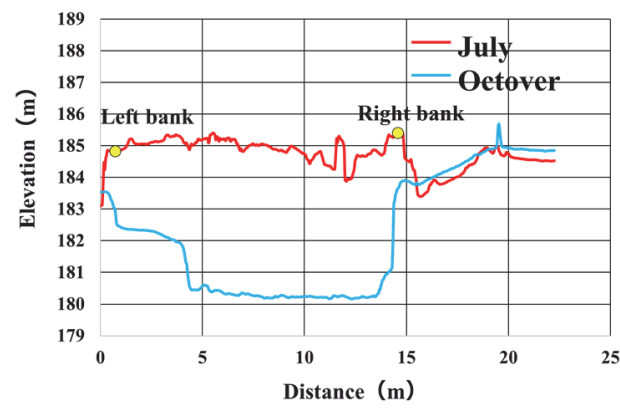

(c) Cross section of the traversal line [2]

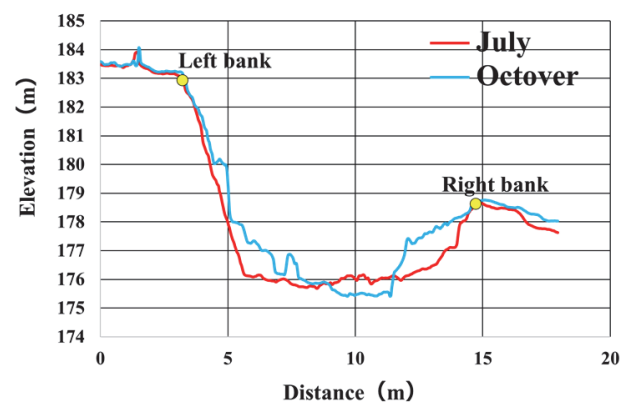

(d) Cross section of the traversal line [3]

Fig.6 The Contour diagram obtained by subtracting the October DSM from the July DSM and cross sections.

removed. In the survey, we recorded the damage situation by field investigation and photographed the target area using UAV (DJI Phantom4 Pro and Mavic Pro). In addition, using Global Navigation Satellite System (GNSS), we obtained the geocoordinates (latitude, longitude, and altitude) of the fixed points, such as huge rocks, land-based structures, and white line on the road. We also measured the cross sections of the river channels. Structure from Motion-MultiVideo Stereo (SfM-MVS) was conducted by reflecting the survey results as Ground Control Point (GCP) and using images from the UAV. Moreover, the Digital Surface Model (DSM) and orthoimages were created to understand the situation of the afflicted area and the amount of sediment deposited due to the disaster.

\section{(3) Field survey results and discussion}

The debris flow that occurred in the Osogoe district destroyed the houses near the left bank of the Higashi River and flowed into the Higashi River. Moreover, an inundation that overflowed from a river occurred in the Osogoe district and some buildings were damaged by the inundation.

Figure 4 shows the orthoimage ( $5 \mathrm{~cm}$ resolution) of the confluence of the debris flow and the Higashi River that was created from the image taken by the UAV in July of 2018. It is confirmed that sediment and driftwoods carried by the debris flow had been filling up the river channel at the time of the disaster.

Figure 5 shows the orthoimages around the afflicted area and the damage situations. Sediments and driftwoods were deposited in the river channel, and a lot of driftwoods were caught between the bridge piers. 
In addition, sediments and wood fragments carried by the flood were deposited on the road. From the situation of the afflicted area, it was confirmed that after a lot of driftwoods were supplied into the Higashi River channel, the driftwoods formed a dam and a detour flow occurred on the road due to the driftwoods caught by the downstream bridge pier. The detour flow was eroded the ground of Shuhoku Elementary School and re-entered the Higashi River. This situation indicates two things. First, during the disaster, river inundation occurred because of the remarkable rise of the riverbed. Second, the significant rise in the riverbed could be due to: 1) sediment and driftwood carried into the Higashi River by the debris flow and 2) river clogging caused by the driftwoods caught between the bridge piers.

Figure 6 (a) shows a contour diagram obtained by subtracting the October DSM from the July DSM created by SfM-MVS. Immediately after the disaster, it was confirmed that the riverbed generally rose from the confluence to the bridge. As a validation, we extracted DSM data from the confluence to the bridge and found that the riverbed in July of 2018 (immediately after the disaster) increased by $1.50 \mathrm{~m}$ on average within the range. On the other hand, there was almost no difference in the riverbed downstream from the bridge, but the riverbed in October of 2018 was $0.42 \mathrm{~m}$ higher on average than the riverbed in July of 2018 (immediately after the disaster). It is assumed that the increased riverbed in the downstream of the Higashi River was due to the inflow of the deposited sediment from the upstream of the bridge after the disaster.

Figure 6 (b), (c), (d) show the cross sections from upstream to downstream in traversal lines of [1], [2], and [3]. The yellow point indicates the river bank. The traversal line of [1] is in the confluence of the debris flow and the Higashi River (Fig. 6 (b)) and it shows that a lot of sediment and driftwoods had been deposited. Moreover, it shows that the height of the part of driftwoods caught between the bridge piers in the traversal line of [2] (Fig. 6 (c)) was more than $5 \mathrm{~m}$ higher than the riverbed before the disaster. On the other hand, the riverbed on the center stream was scoured in the traversal line of [3], which is downstream from the bridge (Fig. 6 (d)) but the river bed on the both banks has generally risen on the same line. It is assumed that the reason for the tendency to deposit in the riverbed on the center stream is the supply of sediments deposited near the bridge after the disaster. Also, the reason for the tendency to scour in the riverbed on the center stream is that deposited sediments scoured only the center stream because the flow was concentrated at the center stream. These results support the observations of the field survey and indicate a high possibility that the cause of the flood
Table 1 Calculation parameters of the Morpho2DH.

\begin{tabular}{|c|c|}
\hline $\begin{array}{c}\text { Static Deposition Sediment } \\
\text { Concentration }\end{array}$ & 0.6 \\
\hline Liquid Behavior Sediment Ratio & 0.2 \\
\hline Minimum Flow Depth (m) & $\mathbf{0 . 0 1}$ \\
\hline Internal Friction Angle (Degree) & 34 \\
\hline Laminar Flow Depth (m) & change \\
\hline Resistance Coefficient & 72 \\
\hline
\end{tabular}

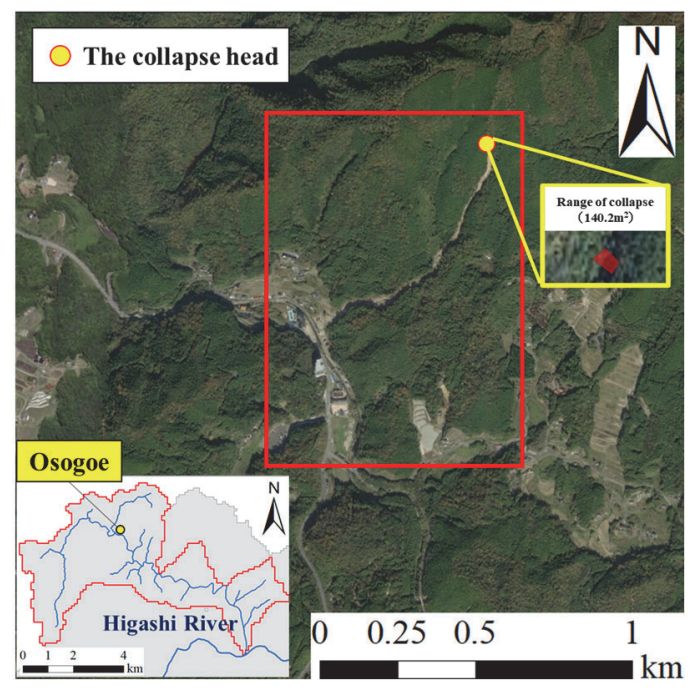

Fig.7 The collapse head and the caluculation area of the debris flow analysis.

in the Osogoe district could be the flowing of sediments and driftwoods carried by the debris flow.

\section{ANALYSIS OF OSOGOE DISTRICT}

\section{(1) Analysis method}

\section{a) Debris flow analysis}

We conducted the debris flow analysis with the morpho2DH solver of iRIC (iRIC Institute, 2019) ${ }^{10)}$ to simulate the debris flow that occurred in the Osogoe district. For the calculation, we have created terrain data combining digital elevation model $(5 \mathrm{~m}$ mesh) and digital surface model ( $1 \mathrm{~m}$ mesh). The digital surface model was published by the Geospatial Information Authority of Japan and the digital surface model was created from the UAV measurement of the field survey. The collapse head area and calculation area are shown in Fig. 7. The collapse head area was determined based on UAV aerial image obtained in the field survey. The collapse head was set only one area in the calculation and the start time of slope failure was the beginning of the calculation. The shape of the collapse area was determined by the aerial photograph after the disaster. The set collapse 
Table 2 Calculation parameters of the RRI model.

\begin{tabular}{|c|c|c|c|}
\hline $\begin{array}{c}\text { Manning's roughness } \\
\text { coefficient }\end{array}$ & 0.035 & $\begin{array}{c}\text { Unsaturated } \\
\text { effective porosity }\end{array}$ & 0.12 \\
\hline Roughness on slope & 0.6 & $\begin{array}{c}\text { Hydraulic } \\
\text { conductivity rate }\end{array}$ & 4 \\
\hline Soil depth(m) & 1.0 & $S_{w}$ & 0.995 \\
\hline $\begin{array}{c}\text { Saturated effective } \\
\text { porosity }\end{array}$ & 0.3 & $S_{d}$ & 0.41 \\
\hline $\begin{array}{c}\text { Saturated hydraulic } \\
\text { conductivity }\end{array}$ & 0.01 & $C_{d}$ & 0.6 \\
\hline & & $C_{w}$ & 1.1 \\
\hline
\end{tabular}

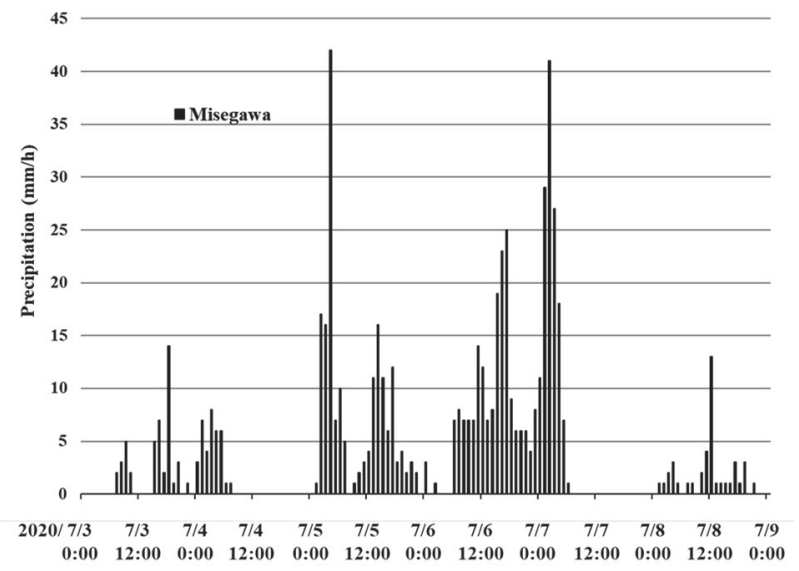

Fig.8 Precipitation data at the time of the disaster (Misegawa rain observatory).

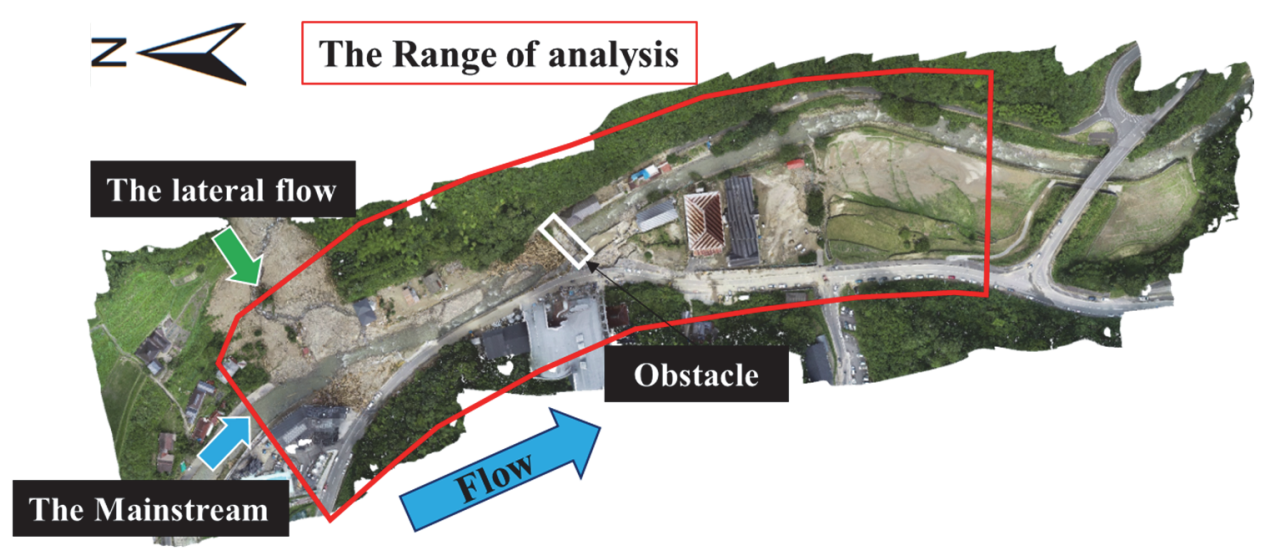

Fig.9 The range of the inundation analysis.

area was $140.2 \mathrm{~m}^{2}$ and the set collapse volume was about $42 \mathrm{~m}^{3}$ as shown in Fig.7. The depth of the slope failure was set at $0.3 \mathrm{~m}$ according to the technical report on the Morpho 2DH solver (Tanaka, 2016) ${ }^{11)}$. A 1-m mesh computation grid was set in the analysis range. In the Morpho2DH solver, the average depth of riverbed sediment (maximum erosion depth) must be set, and the maximum erosion depth was originally determined by conducting a dew rock survey. However, we could not conduct the dew rock survey and the grain diameter survey thus, the maximum erosion depth has been set $0.1 \mathrm{~m}$ and average grain diameter was set at $0.01 \mathrm{~m}$ according to the technical report on the Morpho 2DH solver (Tanaka, 2016) ${ }^{11)}$. Manning's roughness coefficient set the general value 0.03 (Nakatani and Satofka, 2018) ${ }^{12}$. Calculation time interval was set at 0.001 second. The other calculation conditions are indicated in Table 1. Other parameter were determined according to the technical report on the Morpho 2DH solver (Tanaka, 2016) ${ }^{11)}$.

\section{b) Runoff analysis of the Higashi River}

Because the measured data of water level and discharge did not exist in the survey area, we conducted the runoff analysis using the RRI (Precipitation-Runo
ff-Inundation) Model (Sayama, 2014) ${ }^{13)}$ to estimate the discharge that flowed into the Osogoe district during the disaster. The target area of the analysis was the Higashi River Basin (Fig.1), and the precipitation data were obtained at the rain observatories (Kuga, Kugadoboku, Terayama, Misegawa, and Suganodamu). The Thiessen polygons were made with the observed data of the rain per hour. The data of the Misegawa Rain Observatory are shown in the Fig.8. It is confirmed that there were strong hourly precipitations more than 40mm on July 5, 2018 at 4:00 and July 7, 2018 at 2:00. In addition, the residents' testimony that the debris flow was occurred around July 7,2018 at 3:00 was obtained. The analysis period was set from June 28, 2018 at 0:00 to July 9, 2018 at 0:00. For the inundation analysis, we created terrain data from the digital surface model $(5 \mathrm{~m}$ mesh and $10 \mathrm{~m}$ mesh) published by the Geospatial Information Authority of Japan. A $30 \mathrm{~m}$ mesh computation grid was set in the analytical range. The slope calculation time interval was set at 60 seconds, and the river calculation time interval was set at 20 seconds. Incidentally, we needed to estimate the river width $W(\mathrm{~m})$ and river depth $D(\mathrm{~m})$ as first approximation as shown in Eq. 


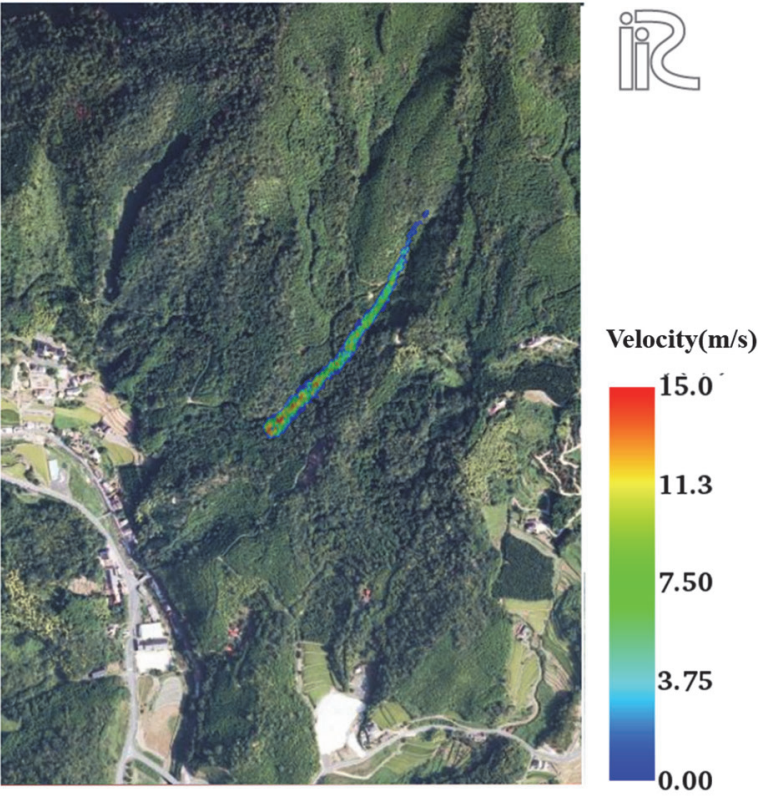

(a) After 50 seconds

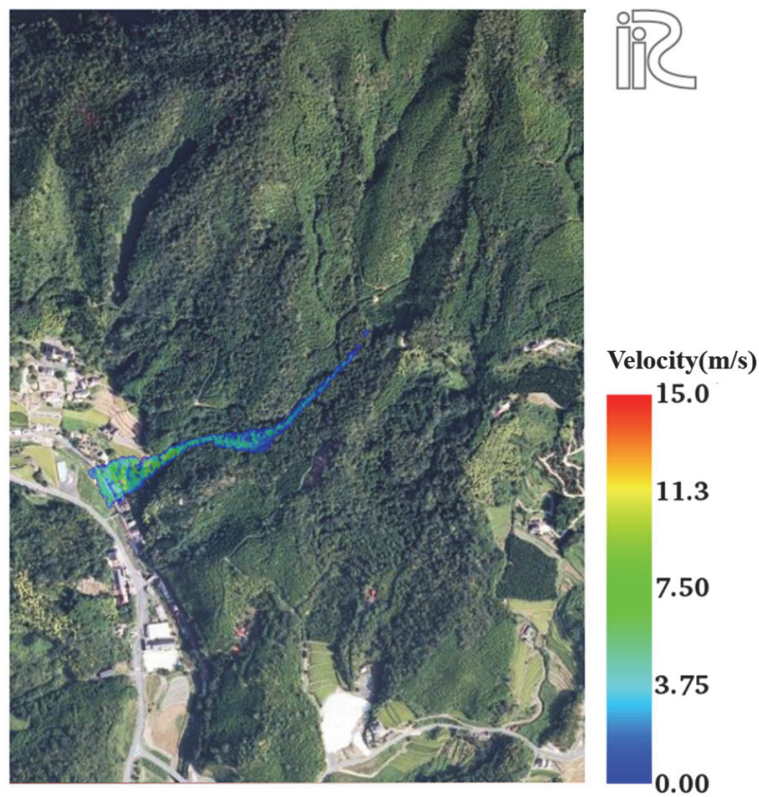

(b) After 100 seconds

Fig.10 The velocity distribution of the debris flow.

(1) and (2) in RRI if we could not get the detailed information on the river cross section ${ }^{14)}$.

$$
\begin{aligned}
& W=C_{W} A^{S_{W}} \\
& D=C_{d} A^{S_{d}}
\end{aligned}
$$

About Eq. (1) and (2), $A$ is intake area $(\mathrm{km})$ and $S_{w}$, $C_{w}, S_{d}$, and $C_{d}$ are river parameters estimated from the available information on the cross section. In the analysis, $S_{w}, C_{w}, S_{d}$, and $C_{d}$ are estimated from the available information on the cross section of three sites in the Higashi River Basin to match the measured river width and depth. The parameter values are shown in Table 2. The parameters except for $S_{w}, C_{w}$, $S_{d}$, and $C_{d}$ were set according to the value of the exercise book of the RRI model (The Japan Society of Hydrology and Water Resources, 2017) ${ }^{15)}$ because these parameters are difficult to estimate.

\section{c) Inundation analysis in the Osogoe district}

As mentioned in Chapter 2, the notable characteristic of the disaster in the Osogoe district was the remarkable rising of riverbed at the time of the disaster due to the inflow of the sediment and driftwoods carried by the debris flow. Therefore, we conducted inundation analysis on two cases to clarify the effect of the inflow of the sediment and driftwoods. Case 1 assumed the river condition at the July survey conducted immediately after the disaster, where sediment deposition and clogged driftwoods in front of the bridge piers were observed, while the condition in the October survey, where sediment deposition and driftwoods were removed, was assumed for Case 2. It was possible to analyze the inundation by using the RRI model. However, we used the Nays2DH-Flood solver of iRIC (iRIC Institute, 2019) ${ }^{10)}$ for the inuIndation analysis because Nays2DH-Flood solver has a function to input river structure, such as a bridge, and it was possible to confirm the details of inundation in two dimensions, such as velocity vector in Nays2DH-Flood solver.

The position of the confluence of debris flow, the orthoimage of the Osogoe district, and the range of the inundation analysis are shown in Fig.9. The terrain data of Case 1 was created with the digital surface model (DSM) data in July, and the terrain data of Case 2 was created with the DSM data in October. The terrain data were created by extracting the DSM data of the field survey area. The calculation time interval was set at 0.01 second. A $1 \mathrm{~m}$ mesh computation grid was set in the analysis range. In each case, Manning's roughness coefficient was set at 0.01 at the road and 0.03 at the river and other land use area. The discharge time series obtained by the runoff analysis of the Higashi River were set to the upstream boundary condition. The downstream boundary condition was free outflow. In addition, the obstacle polygon was set in the analytical range of the bridge in Case 1 in order to set the effect of driftwoods blocking up the river flows.

\section{(2) Analysis result}

\section{a) Debris flow analysis}

The distributions of the flow velocity at 50 and 100 seconds after the beginning of the debris flow are shown in Fig 10. In addition, the elevation variation distribution of the terrain immediately after the debris flow stopped is shown in Fig 11. The situation of the downfall almost matched the trace of the debris flow 


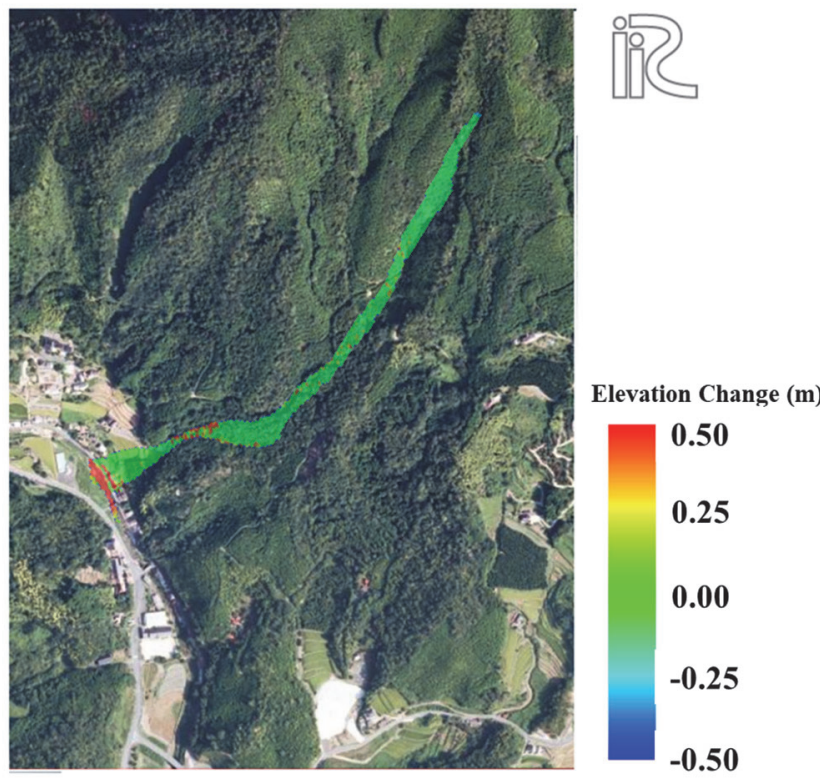

Fig.11 Elevation change.

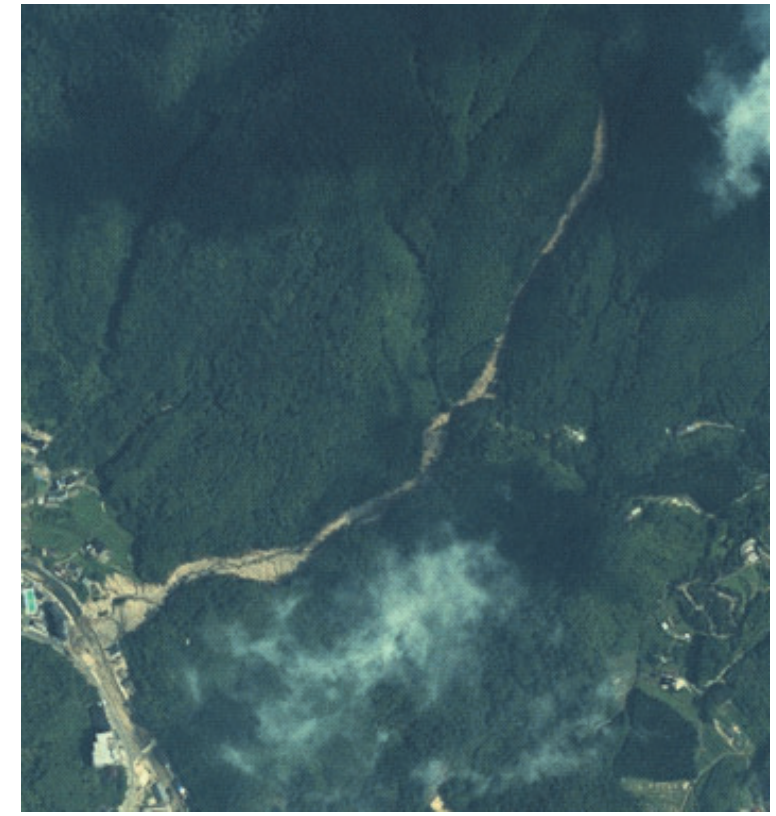

Fig.12 Aerial image of the Osogoe district (2018/7/19).

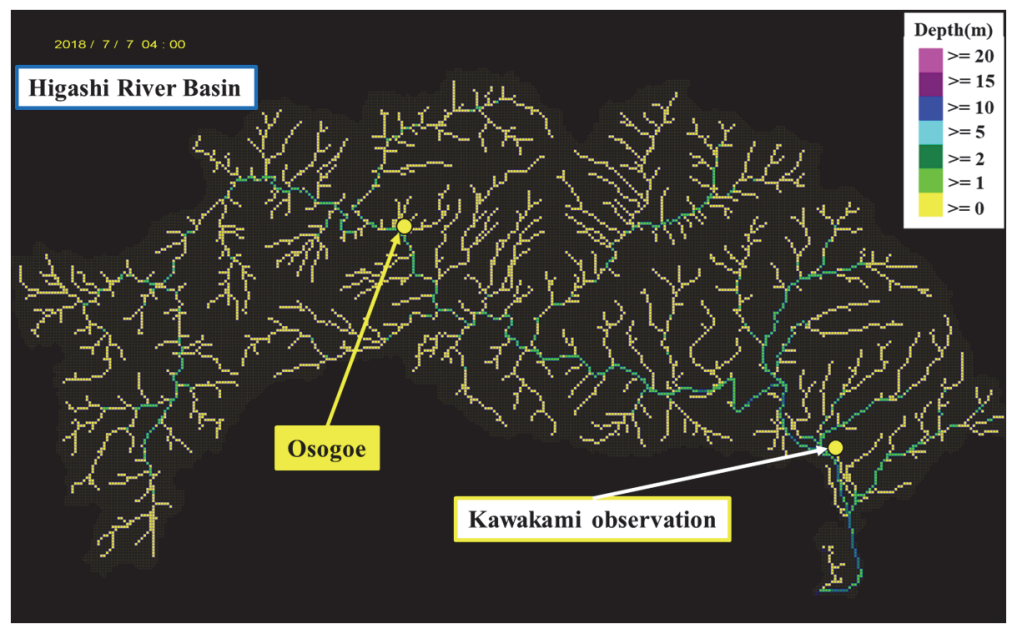

Fig.13 The depth contour of peak time in the Higashi River Basin.

taken by the Geospatial Information Authority of Japan on July 19, 2018 (Fig. 12) ${ }^{16)}$. It was confirmed that the debris flow flowed down along the valley from the collapse point to the Higashi River, expanding its scale. The downflow distance of the debris flow was about $950 \mathrm{~m}$. At 81 seconds after the collapse started, the debris flow reached the settlement in the Osogoe district, and at 84 seconds after the collapse started, the debris flow began to flow into the Higashi River. After the debris flow began to flow into the Higashi River, the debris flow continued to flow into the river for 103 seconds. The debris flow had been flowing at a very high speed $(11.7 \mathrm{~m} / \mathrm{s}$ on average) until it reached the Higashi River. It was considered that the debris flow ran into the Higashi River while uprooting the trees in the mountains. It was confirmed that the debris flow depth had been $0.42 \mathrm{~m}$ on average until it flowed into the Higashi
River, and the sediment had been deposited approximately $2135 \mathrm{~m}^{3}$ in the river. The amount of the sediment deposition was approximately $2480 \mathrm{~m}^{3}$. Therefore, it was considered that the result of the calculation almost matched the actual result. The results of the debris flow analysis in the Osogoe district indicated that: 1) the debris flow in the Osogoe district ran down the mountains while eroding a large amount of the sediment, and 2) the debris flow merged with the Higashi River after 84 seconds and approximately $2135 \mathrm{~m}^{3}$ of sediment was transported into the channel in about 103 seconds. One thing to note here is that the results of calculation were approximate values, because the set mean diameter was $0.01 \mathrm{~m}$.

\section{b) Runoff analysis of the Higashi River}

The water depth distribution analyzed by the RRI model of the Higashi River Basin at the peak (July 7, 2018 at 4:00) is shown in Fig.13. It was assumed that 


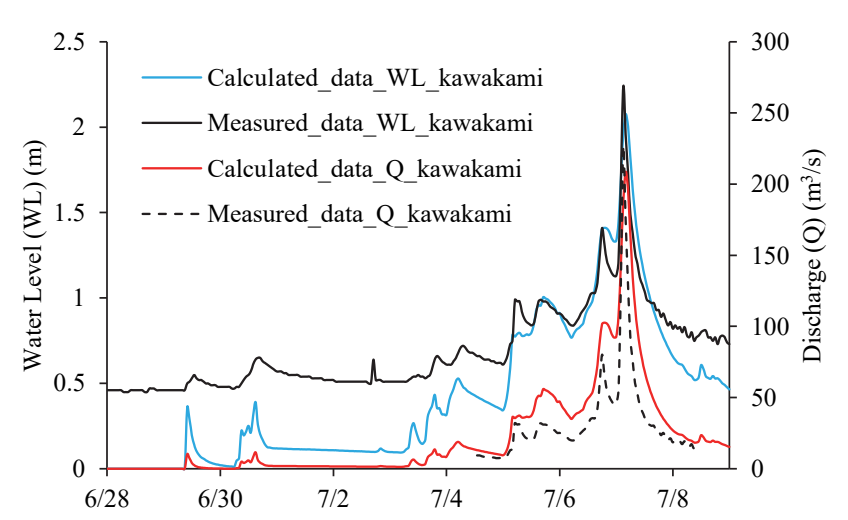

Fig.14 Comparison between the measured WL and calculated WL.

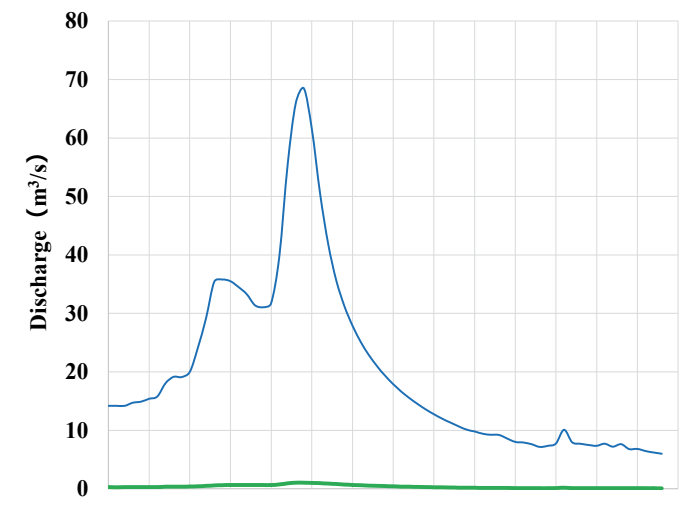

Fig.15 Derived discharge time series of the Osogoe district.

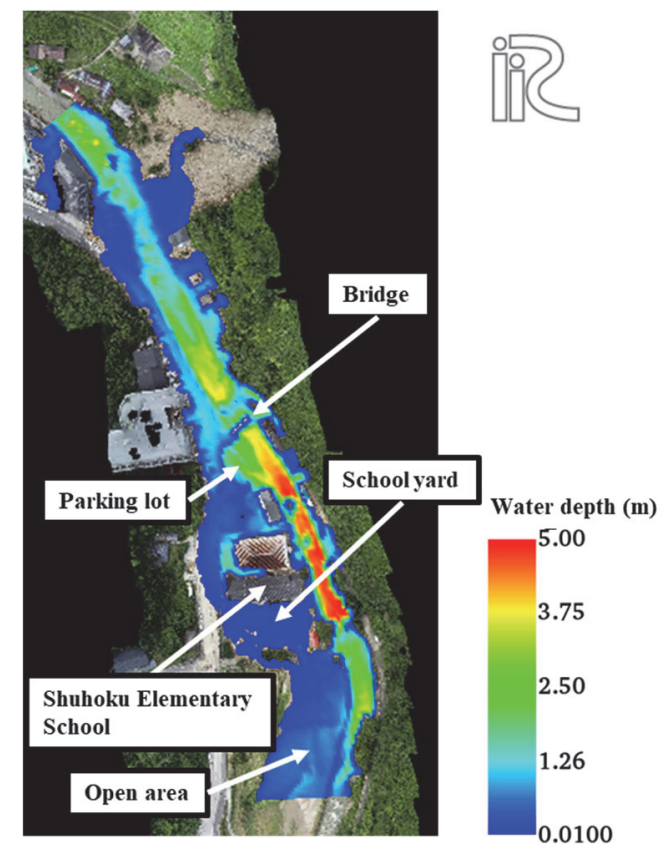

(a) Case1

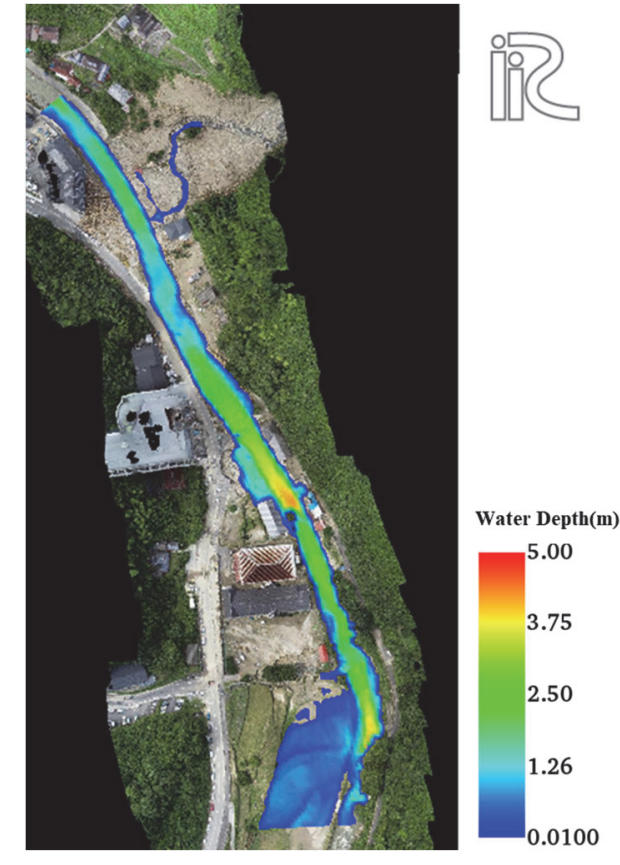

(b) Case2

Fig.16 The depth contour at the peak calculated from the inundation analysis.

the river discharge increased rapidly during the disaster because the Osogoe district is located near the confluence where the water depth tends to easily rise. Figure 14 shows the comparison between the calculated values and the measured values of the water depth and discharge time series at the Kawakami Observatory (shown in Fig.1). Although the normal stage of water and the periods of low precipitation were underestimated, it was confirmed that the fluctuation of the discharge and depth against the target rain approximately matched the measured values. In terms of the peak (July 7, 2018 at 3:00), the measured water depth and discharge were $2.240 \mathrm{~m}$ and $225.7 \mathrm{~m}^{3} / \mathrm{s}$, respectively. On the other hand, the calculated water depth and discharge were $2.077 \mathrm{~m}$ and $208.6 \mathrm{~m}^{3} / \mathrm{s}$, respectively, in terms of the peak (July 7 , 2018 at 3:00), indicating that the calculated water depth and discharge had enough accuracy.
The temporal variation in the discharge that flowed into the Osogoe district was obtained by the runoff analysis (Fig. 15). In the Osogoe district, there were two inflows from the mainstem of the Higashi river and the valley where the debris flow occurred. Therefore, the discharge time series for each inflow was estimated. The peak value was $68.52 \mathrm{~m}^{3} / \mathrm{s}$ and the discharge increased rapidly in July 7, 2018 at 0:00 (20 hours after the start of the inflow on July 6, 2018 at 4:00).

\section{c) Inundation analysis in the Osogoe district}

The discharge of the upstream boundary and the lateral flow set for inundation analysis were estimated by the runoff analysis in the Higashi River Ba$\sin$. The downstream boundary was free outflow. The contour diagrams of water depth $(\mathrm{m})$ at the time of the flood peak runoff (July 7, 2018 at 4:00) of Case 1 and Case 2 are shown in Fig. 16 (a) and Fig. 16 (b), 


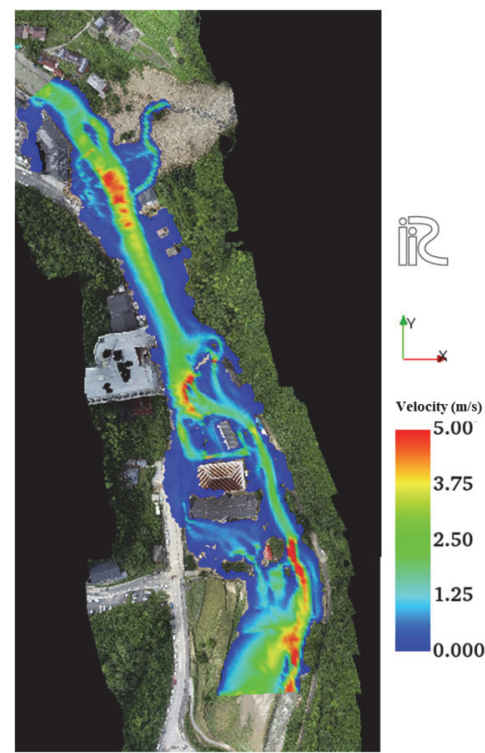

(a) Case 1

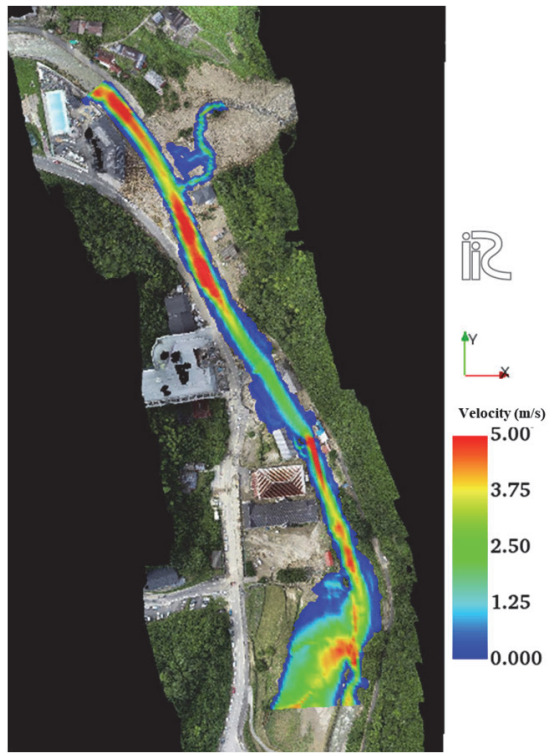

(b) Case2

Fig.17 The velocity contour at the peak calcurated from the inundation analysis.

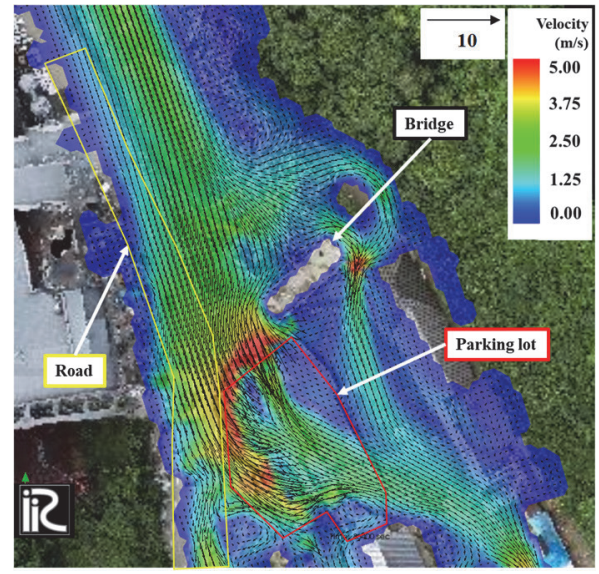

(a) Case 1

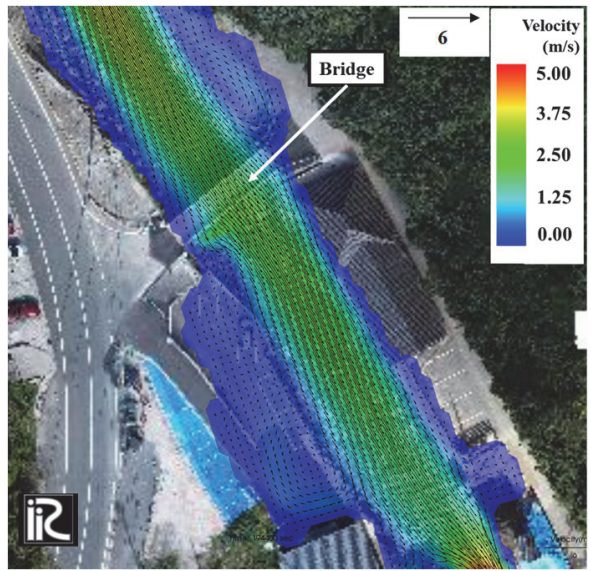

(b) Case2

Fig.18 The velocity around the bridge at the peak.

respectively. In the Case 1, the flow has reached up to the schoolyard of the Shuhoku Elementary School after 12 hours and 10 minutes (July 6, 2018 at 4:10) from the start of the calculation because of the detour caused by the driftwood. It indicated that the entire Shuhoku Elementary School (including the road section) was inundated at the peak. Moreover, it was confirmed that the water depth had been over $5 \mathrm{~m}$. The inundation area of Case 1 matched the flow trace in the orthoimage. On the other hand, in Case 2, Shuhoku Elementary School was not inundated, and the flood flow reached up to a range of the parking lot and the open area under the Shuhoku Elementary School even at the peak. Moreover, the maximum water depth was under $5 \mathrm{~m}$ in the calculated area.

The contour diagrams of the velocity $(\mathrm{m} / \mathrm{s})$ at the time of the peak of Case 1 and Case 2 are shown in Fig. 17 (a) and Fig. 17 (b), respectively. It was confi rmed that the inflow velocity to the parking lot near the bridge was faster than other places in Case1, suggesting that the inflow to the parking lot matched the location of the large-scale erosion identified in the field survey. In contrast, in Case 2, it was confirmed that: 1) the large-scale inundation did not occur even at the peak and 2) the high-speed area was only at the river channel.

The contour and vector diagrams of the velocity of Case 1 and Case 2 are shown in Fig. 18 (a) and Fig. 18 (b), respectively. In the Case 1, it was clarified that the velocity of the flow was over $4 \mathrm{~m} / \mathrm{s}$ and the road near the Shuhoku Elementary School and the bridge were completely inundated. In contrast, the inundation range in Case 2 was smaller than that in Case 1 although the parking lot was inundated.

Our results indicated that: 1) the inundation in the Osogoe district would not have occurred without the 
debris flow and 2) it is necessary to make a countermeasure for the inundation in the river where a debris flow may flow directly into the river and even outside of the possible inundation area.

\section{CONCLUTION}

The following are the details of the complex disaster in the Osogoe district after the heavy rain on July 7, 2018. After the collapse of the headwall in the afflicted area around 3:00, the debris flow flowed down, including a lot of sediment and driftwoods (the front velocity was $11.7 \mathrm{~m} / \mathrm{s}$ on average and the flow depth was $0.42 \mathrm{~m}$ on average). The debris flow merged with the Higashi River, and sediment about $2135 \mathrm{~m}^{3}$ was deposited in the river channel. The inundation was caused by the deposition at the confluence and the driftwoods blocking up the river flow at the bridge. As a result, the flood flow up to the Shuhoku Elementary School and reached created a flow channel to the schoolyard at the flood peak runoff (July 7, 2018 at 4:00).

The causes of the flood in the Osogoe district were: 1) the significant rise in the riverbed due to the flowing of sediments and driftwoods carried by the debris flow and 2) the driftwoods blocking up the river flows at the bridge. In addition, the situation of the inundation analysis showed that the inundation would not have occurred without the debris flow's inflow into the river. The area where the debris flow occurred was included in the landslide-prone. Therefore, an effective management strategy for the afflicted area like the Osogoe district needs to include predicting the direct inflow of the debris flow with a lot of sediment and driftwoods to the river segments.

ACKNOWLEDGMENT: This study was supported by The River Foundation and the Grants-in-Aid for Scientific Research of Ministry of Education, Culture, Sports, Science and Technology. We thank S. Miyazono for editing our manuscript.

\section{REFERENCES}

1) Japan Meteorological Agency, The factor and characteristics of "The heavy rain in July 2018", pp. 1-2, 2018. (in Japanese)

2) Tsubaki, R., Asai, K., Nakamura, A., Tomura, K., Kawahara, Y. and Nagano, H.: Inundation flow in mountainous village in the Asa river basin during 2010 July torrential precipitation event, Journal of Japan Society of Civil Engineers, Ser. B1 (Hydraulic Engineering), Vol. 70, No. 4, pp. I_1441-I 1446, 2014. (in Japanese)
3) Hashimoto, A., Kawai, K. and Tai, A.: Numerical analysis of inundation flow due to heavy precipitation in Amami Oshima island, Journal of Japan Society of Civil Engineers, Ser. B1 (Hydraulic Engineering), Vol. 71, No. 4, pp. I_1453-I_1458, 2015. (in Japanese)

4) Komuro, T., Akamatsu, Y., Yamaguchi, K., Watanabe, Y., Moriya, H. and Nihei, Y.: Investigation of sediment flooding in Souzu river, Chikugo river system by the northern Kyushu heavy rain in July 2017, Journal of Japan Society of Civil Engineers, Ser. B1 (Hydraulic Engineering), Vol. 74, No. 4, pp. I_1189-I_1194, 2018. (in Japanese)

5) Yamazaki, Y., Egashira, S. and Nagumo, N.: A method to estimate sediment runoff due to heavy precipitation in mountainous watershed, Journal of Japan Society of Civil Engineers, Ser. B1 (Hydraulic Engineering), Vol. 74, No. 4, pp. I_931-I_1936, 2018. (in Japanese)

6) Egashira, S., Harada, D., Nagumo, N., Yamazaki, Y. and Yorozuya, A.: A method to predict fine sediment runoff focusing on debris cones resulting from landslides and debris flows - sediment hazards occurred at Akadani drainage ba$\sin$ in July, 2017 -, Journal of Japan Society of Civil Engineers, Ser. B1 (Hydraulic Engineering), Vol. 74, No. 4, pp. I_925-I_930, 2018. (in Japanese)

7) Harada, D. and Egashira, S.: Flood flow characteristics with fine sediment supply and drift woods - Analysis on the Akatani River flood hazards in July, 2017, Journal of Japan Society of Civil Engineers, Ser. B1 (Hydraulic Engineering), Vol. 74, No. 4, pp. I_937-I_942, 2018. (in Japanese)

8) Iwakuni City Office: Flood/inundation predicted area, $<$ https://www.city.iwakuni.lg.jp/hazardmap/index_en.html?lay=kozui>, 2019.

9) Iwakuni City Office: Landslide Debris flows warning area, $<$ https://www.city.iwakuni.lg.jp/hazardmap/index_en.html?lay=dosya $>, 2019$.

10) iRIC-UC, iRIC Software, H30.7, http://i-ric.org/ja/, 2018.

11) Tanaka, H.: Debris flow analysis by using iRIC, Applied Technology Co., Ltd., OGI Technical Reports, Vol. 24, pp. 39-44, 2016. (in Japanese)

12) Nakatani, K. and Satofuka, Y.: Debris flow scale and landform data resolution effect on influence area, Journal of Japan Society of Civil Engineers, Ser. B1 (Hydraulic Engineering), Vol. 74, No. 4, pp. I_1201-I_1206, 2018. (in Japanese)

13) Sayama, T.: Precipitation-Runoff-Inundation (RRI) Technical Manual, Technical Note of PWRI, No.4277, Public Works Research Institute, 2014.

14) Sayama, T., Tatebe, Y., Fujioka, S., Ushiyama, T., Yorozuya, A. and Tanaka, S.: An emergency response-type precipitation-runoff-inundation prediction for 2011 Thailand flood, Journal of Japan Society of Civil Engineers, Ser. B1 (Hydraulic Engineering), Vol. 69, No. 1, pp. 14-19, 2013. (in Japanese)

15) Japan Society of Hydrology and Water Resources: RRI model active seminar, pp. 66, 2017.

16) Geospatial Information Authority of Japan: Aerial photography (2018.7), <https://saigai.gsi.go.jp/1/H30_07gouu/ 0719iwakuni/photo/qv/0031.jpg>, 2019.

(Received August 31, 2020) (Accepted October 20, 2020) 